\title{
Pilot Study on the Preparation of Fiber Cement Panel using Calcium Silicate Slag
}

\author{
ZHAN Jiayu ${ }^{1, a}$, GENG Chunlei, ${ }^{1, b}$, YANG Feihua ${ }^{1, c}$, LI Wanmin $^{1, d}$,YANG \\ Chuang ${ }^{1, e}$, YANG Zhijie ${ }^{2, f}$
}
${ }^{1}$ State Key Laboratory of Solid Waste Reuse for Building Materials, Beijing Building Materials Academy of Science Research, Beijing100041, P.R.China

\author{
${ }^{2}$ National Energy Key Lab of High Alumina Coal Development and Utilization, Datang International \\ High Alumina Coal R\&D Center, Inner Mongolia 010321, P.R.China \\ azhanjiayu1981@126.com, ${ }^{b} 18611669792 @ 163 . c o m,{ }^{c}$ chyangfeihua@126.com, \\ diwanmin2008@sina.com, eyangchuang198508@163.com, 'yzj830602@163.com
}

\begin{abstract}
Keywords: Calcium silicate slag, Fiber cement panel, Physical property, Mechanical property Abstract. Calcium silicate slag is a waste discharged during alumina extraction process from fly ash was investigated. In this study, calcium silicate was used as raw material to substitute part of Portland cement to produce fiber cement panel. The fiber cement panel was produced via extruding process. The physical and mechanical properties were extensively investigated, which meet all requirements of Chinese standard. The findings from this study indicated that calcium silicate slag has potential application in the production of fiber cement products.
\end{abstract}

\section{Introduction}

Calcium silicate slag is a solid waste generated during alumina extraction from high-alumina fly ash via alkaline process[1]. Calcium silicate is mainly composed of $\mathrm{CaO}$ and $\mathrm{SiO}_{2}$, with the major crystalline phases of $\mathrm{C}_{2} \mathrm{~S}$ and $\mathrm{C}_{3} \mathrm{~A}$. About 2.2 2.5 tons of calcium silicate slag will be discharged when producing 1 ton of $\mathrm{Al}_{2} \mathrm{O}_{3}$. The disposal of such a large quantity of waste requires a lot of land and has caused many serious environmental problems such as soil contamination and water pollution.

The reuse of calcium silicate slag has been carried out in many fields. Jinshan Zhang et al.[2] used calcium silicate in combination with gypsum, fly ash, cement and reinforcing fiber to prepare calcium silicate board with flexural strength of up to 9.2 MPa. Jiang Liu et al.[3] investigated the use of calcium silicate slag as cement admixture. The compressive strength of non-dealkalizated calcium silicate slag cement is higher than dealkalizated calcium silicate slag cement during the early hydration. The cement compressive strength using dealkalizated calcium is apparently higher than using non-dealkalizated calcium silicate slag at 90 days. Ping Wen [4] used calcium silicate slag as a high-volume component of raw meal to replace limestone to produce Portland cement clinker. Jinshan Zhang et al [5] found that calcium silicate slag could be used to produce aerated concrete. With the content of calcium silicate slag up to $50 \%$, the strength and density can meet the request of Chinese standard. Na Zhang [6] produced cementitious material from calcium silicate slag, which exhibited excellent physical and mechanical properties. The leaching toxicity and radioactivity test results indicated that the cementitious material is environmentally acceptable.

Fiber cement panel, because of its outstanding fireproof, moistureproof, light-weight, eco-friendly properties, has been widely used in decoration field. In this paper, an investigation into the production of fiber cement panels using calcium silicate slag is presented. The aim of the present study is to investigate the feasibility of the fiber cement panel composed of calcium silicate slag. The hydration products, physical and mechanical properties of panels were evaluated. 


\section{Experimental Section}

Materials. Materials used in this study included calcium silicate slag, Portland cement, silica sand, pulp fiber, PP fiber and additives. Calcium silicate slag was supplied by Datang international high alumina Coal R\&D center.

Methods. $50 \%$ percent of cement replaced by calcium silicate slag was adopted in this study. Water/binder ratio of mix designs was specified at 0.3 . The fiber cement panels of dimensions $1.2 \mathrm{mx}$ $2.4 \times 8 \mathrm{~mm}$ were produced on an extruding production line. The panels were cured in a moist room at more than $95 \%$ relative humidity and at a temperature of $25^{\circ} \mathrm{C}$ for $48 \mathrm{~h}$.

Characterization. The chemical composition was analyzed using X-ray fluorescence spectrometer. RIGAKU Ultima IV XRD equipped with $\mathrm{Cu}$ target was used for analyzing minerals. The physical and mechanical properties of fiber cement panels were carried out according to the Chinese standard JC/T 412.1-2006.

\section{Results and Discussion}

Fiber cement panels were produced on an extruding production line. The production process was illustrated in Fig.1.

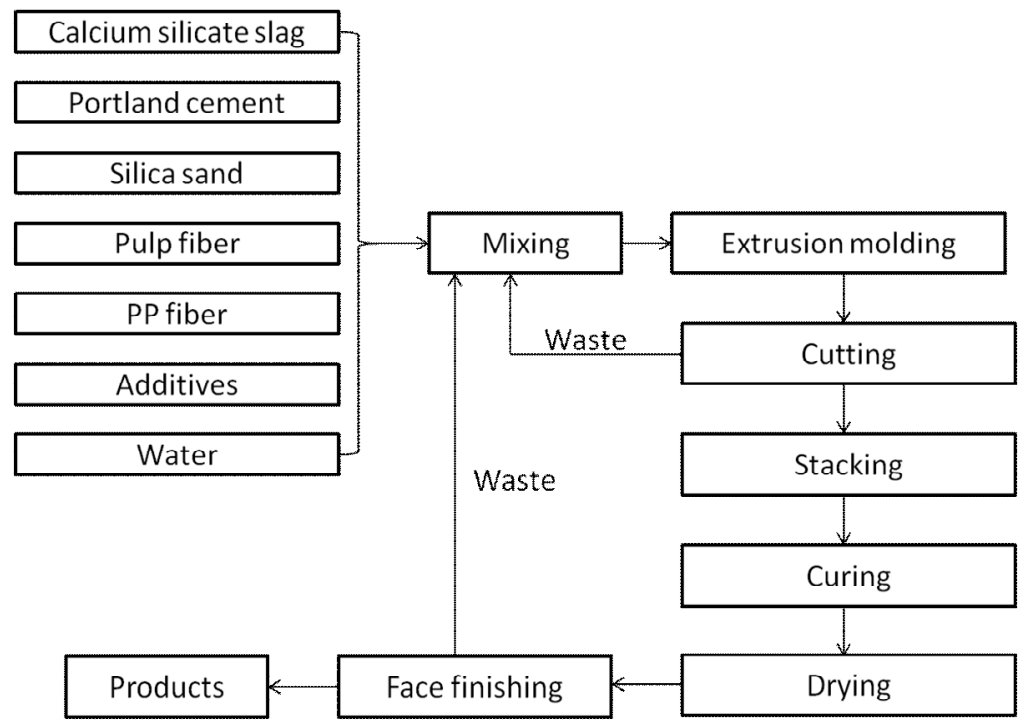

Fig.1 Production process of fiber cement panel

Raw materials including calcium silicate slag, Portland cement, silica sand, pulp fiber, PP fiber, additives and water in the certain proportion get into mixed system from feeding device, mix to form mortar. Pulp fiber should be disposed through defibrination prior to use. The mortar was extruded through a die to form a continuous panel. The panel was then cut to the specified size and placed onto a pallet automaticlly and then cured at a curing room. The cured panels were dried and face finished to form products.

Table 1. Chemical composition of fiber cement panel

\begin{tabular}{cccccccccc}
\hline LOI & $\mathrm{SiO}_{2}$ & $\mathrm{Al}_{2} \mathrm{O}_{3}$ & $\mathrm{Fe}_{2} \mathrm{O}_{3}$ & $\mathrm{CaO}$ & $\mathrm{MgO}$ & $\mathrm{SO}_{3}$ & $\mathrm{Na}_{2} \mathrm{O}$ & $\mathrm{K}_{2} \mathrm{O}$ & $\mathrm{TiO}_{2}$ \\
\hline 16.535 & 28.215 & 3.676 & 2.306 & 39.572 & 1.953 & 1.407 & 0.529 & 0.247 & 0.386 \\
\hline
\end{tabular}

The chemical composition of fiber cement panel was given in Table 1. The panel consists mainly of $\mathrm{CaO}, \mathrm{SiO}_{2}$ and $\mathrm{Al}_{2} \mathrm{O}_{3}$. 


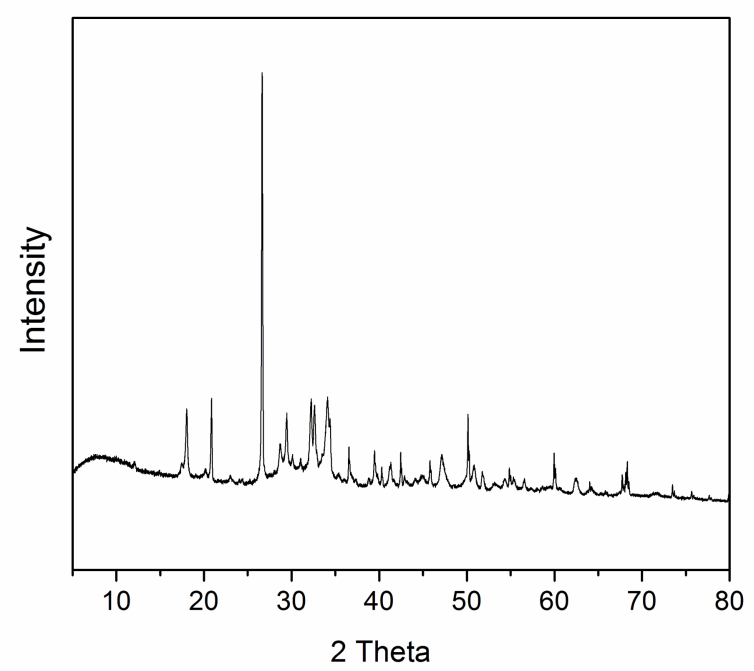

Fig.2. XRD pattern of fiber cement panel

The XRD spectrum of fiber cement panel is shown in Fig. 2. The major mineral components of panel are $\mathrm{SiO}_{2}, \mathrm{Ca}(\mathrm{OH})_{2}, \mathrm{C}_{2} \mathrm{~S}$, and $\mathrm{C}_{3} \mathrm{~S}$. In our previous study[7], it has been confirmed that calcium silicate slag has hydration reactivity. Therefore, the major reaction during the curing process was the hydration reaction of cement and calcium silicate slag, which formed the final properties of panel.

Table 2. Physical and mechanical properties of fiber cement panels

\begin{tabular}{|c|c|}
\hline Item & Result \\
\hline Density, $\mathrm{g} / \mathrm{cm}^{3}$ & 1.72 \\
\hline Water absorption , \% & 7.8 \\
\hline Impermeability & $\begin{array}{l}\text { There is no wetting mark and water drop on } \\
\text { the other side of panel after } 24 \mathrm{~h} \text { test. }\end{array}$ \\
\hline Swelling rate , \% & 0.317 \\
\hline Incombustibility & $\begin{array}{l}\text { Incombustibility comes up to the grade A } \\
\text { requirements of GB 8624-1997 }\end{array}$ \\
\hline Freeze-thaw durability & $\begin{array}{l}\text { There is no appearance of change and } \\
\text { detachment after } 25 \text { times of freeze-thaw } \\
\text { cycles. }\end{array}$ \\
\hline Flexural strength, $\mathrm{MPa}$ & $\begin{array}{l}\text { 17.3(air-dried condition) } \\
\text { 11.4( water-saturated condition) }\end{array}$ \\
\hline
\end{tabular}

As shown in Table 2, the physical and mechanical properties of fiber cement panels composed of calcium silicate slag meet all the requirements of Chinese standard JC/T 412.1-2006(Fiber cement flat sheets). The panel exhibits excellent impermeability, incombustibility, durability and mechanical property. The flexural strength has reached to the level of grade III. These results confirmed that calcium silicate slag can be effectively used in the production of fiber cement panel.

\section{Conclusions}

We have investigated the application of calcium silicate slag which was generated from the alumina extraction from fly ash in the production of fiber cement panel. The panel consists mainly of $\mathrm{CaO}, \mathrm{SiO}_{2}$ and $\mathrm{Al}_{2} \mathrm{O}_{3}$, with main mineral phases of $\mathrm{SiO}_{2}, \mathrm{Ca}(\mathrm{OH})_{2}, \mathrm{C}_{2} \mathrm{~S}$, and $\mathrm{C}_{3} \mathrm{~S}$. The physical and mechanical properties meet the requirement of Chinese standard, suggesting the calcium silicate slag can be used in the production of fiber cement panels. 


\section{Acknowledgements}

This work was financially supported by the Beijing Municipal Science and Technology Project (No.Z151100004915009).

\section{References}

[1] S.J.Song, D.S.Kong, L.H.Wang and X.W.Bai: Yunnan Chemical Technology Vol.40 (2013), p.52 (in Chinese)

[2] J.S. Zhang, J.P.Ye, J.M.Sun, Y.D.Cao and Z.Z.Geng: New Building Materials Vol.1 (2014), p.54 (in Chinese)

[3] J. Liu, J.B.Zhang, J.M. Sun, H.X.Wang, J.Y.Ye and D.Shi: New Building Materials Vol.12 (2012), p.37 (in Chinese)

[4] P.Wen: Research\&Application Vol.5 (2012), p. 54 (in Chinese)

[5] J.S.Zhang, J.M.Zhao, J.P.Ye, Z.Z.Geng and Y.T.Zheng : Fly Ash Comprehensive Utilization Vol.1 (2013), p. 40 (in Chinese)

[6] N.Zhang, H.Li, Y.Zhao and X.Liu: J.Hazard.Mater Vol.306 (2016), p.67

[7] J. Zhan, C.Geng, F.Yang, W.Li, C.Yang and Z. Yang: 4th International Conference on Sensors, Measurement and Intelligent Materials (2015), p. 650 